\title{
The Association between Accreditation Status, Patient Socio- Economic Factors, Insurance Type, Patient Perceived Quality of Service, and Satisfaction at Community Health Center
}

\author{
Farahdila Mirshanti'), Didik Tamtomo²), Bhisma Murti') \\ 1)Masters Program of Public Health, Universitas Sebelas Maret \\ 2)Department of Anatomy, Faculty of Medicine, Universitas Sebelas Maret
}

\begin{abstract}
Background: Being one of the most important elements in the healthcare system, Community Health Center has been promoted to improve its quality and capacity of services. Accreditation is a method that can be used to improve and measure the quality of health service. Quality service improvement is expected to enhance patient satisfaction. This study aimed to investigate the associations between accreditation status, patient socio-economic factors, insurance type, patientperceived quality of service, and satisfaction at Community Health Center.

Subjects and Method: This was an analytic observational study with cross-sectional design. This study was conducted at Community Health Center in Surakarta, Central Java from June to July 2017. A total of 8 Community Health Centers with different accreditation status (not accredited, lowest, medium, and highest) were selected for this study. A sample of 200 patients were selected from the 8 Comunity Health Centers by proportional random sampling. The independent variables were accreditation status, patient education level, family income, and insurance type. The dependent variables were perceived the quality of service and patient satisfaction. The data were collected by a set of pre-tested questionnaires. Accreditation status was identified from the record at District Health Office. Data were analyzed by path analysis.

Results: Patient satisfaction was associated with Commuity Health Center acrreditation status $(b=0.39 ; \mathrm{SE}=0.22 ; \mathrm{p}=0.069)$, perceived quality of service $(b=0.05 ; \mathrm{SE}=0.02 ; \mathrm{p}=0.022)$, patient education level $(b=-1.16 ; \mathrm{SE}=0.48 ; \mathrm{p}=0.017)$, and insurance type $(\mathrm{b}=0.61 ; \mathrm{SE}=0.31 ; \mathrm{p}=0.044)$. Perceived quality of health services was associated by accreditation status $(b=2.22 ; \mathrm{SE}=0.74 ; \mathrm{p}=$ o.003), patient education level $(b=-4.51 ; \mathrm{SE}=1.68 ; \mathrm{p}=0.007)$, and insurance type $(\mathrm{b}=2.79 ; \mathrm{SE}=$ 1.06; $\mathrm{p}=0.008$ ). Family income did not show statistically significant association with perceived quality of health service $(b=-0.17 ; \mathrm{SE}=0.11 ; \mathrm{p}=0.123)$.

Conclusion: Patient satisfaction is associated with Community Health Center accreditation status, perceived quality of service, patient education level, and insurance type. Perceived quality of health services is associated with accreditation status, patient education level, and insurance type.
\end{abstract}

Keywords: patient satisfaction, perceived quality of service, accreditation status, Community Health Center

\section{Correspondence:}

Farahdila Mirshanti. Masters Program of Public Health, Sebelas Maret University, Jl. Ir. Sutami 36A, Surakarta, Central Java. Email: fmirshanti@gmail.com. Mobile: +628121534393.

\section{BACKGROUND}

Primary health services have had several changes and improvements in the system to improve its service capacity to be more effective, quality, uniform and safe. In Indonesia, in order to realize Universal Health Coverage in 2019, the government carries out various strengthening of health services both in the first-level health facilities and the reference level (Naili, 2016).

One of the ways to improve the quality of service and the patient safety in primary health care facilities is through the implementation of quality improvement 
Journal of Health Policy and Management (2017), 2(1): 91-100

https://doi.org/10.26911/thejhpm.2017.02.01.08

initiatives. There are several strategies to encourage the use of Quality Improvement (QI) in primary health care facilities. One of them is through external assessment mechanisms such as accreditation (O'Beirne et al., 2013). Some countries choose accreditation as a means of measuring, reporting, and improving quality and QI in primary health care facilities. Accreditation standards for primary health care were established first in Australia in the early 1990s. Afterwards, New Zealand, the United States, Indonesia, and several countries in Europe develop these standards. The Indonesian government conducts community health center facilities through accreditation. The Ministry of Health targets 5,600 out of a total of 9,500 community health centers in Indonesia in 2019 must be accredited (Naili, 2016).

Accreditation is a self-assessment based on a set of standards that has been established, a survey in a place by a group of skilled assessor from outside the organization, assessing the degree of compliance on a standard, a written report with or without recommendations, and giving or rejecting an accreditation status. Accreditation measures every activity based on established standards and/or norms of activities to obtain reliable results of measuring the quality and safety of health services (Nicklin, 2009).

Accreditation has been successfully used to improve patient outcomes in acute or emergency health services. However, it has not known whether these findings also apply to primary health care. In addition, the QI process and accreditation in primary health services is still very less known that it can affect service outcomes, cost and service utilization, patient-perceived quality of service, and healthcare providers-perceived quality of service including health workers (O'Beirne et al., 2013; Nicklin, 2009).

According to Lovelock and Wright (2005), quality of care can be measured by comparing perceptions between expected service and perceived and perceived health services by customers or patients. Quality is very subjective, depending on the perception, system of values, social background, education, economy, and culture of the community or personal associated with a health care. In addition, an individual socio-economic status also affects the awareness of having health insurance.

According to Rowland et al., (2004), satisfaction is the result of evaluations from consumers or patients which describes that a health service has provided a level of pleasure where the level of fulfillment will be more or less. Therefore, satisfaction is one of the most important aspects in the quality of health care for patients.

Based on the background above, this study aimed to investigate the effects of community health center accreditation status, socio-economic factors, and patient insurance participation status on quality of health service and satisfaction given to patients at community health center, Surakarta.

\footnotetext{
SUBJECTS DAN METHOD

\section{a. Study Design}

This study was an analytic observational study with cross-sectional design. The study was conducted at 8 community health centers in Surakarta, from June to August 2017.

\section{b. Population and Sample}

The population in this study was patients in community health centers that were not accredited, basic accredited, middle accredited, and primary accredited. The sampling technique used in this study was multistage sampling which consisted of
} 
consecutive sampling to chose 8 out of 17 community health centers in Surakarta (2 community health centers have not been accredited, basic accredited, middle accredited, and primary accredited), and proportional random sampling to obtain 200 patients as samples proportionally from each community health center that has been selected previously.

\section{c. Study Variables}

This study analyzed six variables which consisted of dependent and independent variables. The dependent variables were quality of service and patient satisfaction. The independent variables were accreditation status, patient education level, family income, and insurance participation status.

\section{d. Operational Definition of Variables}

Accreditation status was defined as the result of the accreditation survey which was determined by the surveyor and the decision of the meeting of an independent accreditation institution, which was proven by an accreditation certificate, which consisted of: main accredited, middle accredited, basic accredited, and not accredited

Family income was defined as income per capita per month which was calculated from the average amount of income received by the family.

The education level was defined as the status of formal education through a structured and tiered education pathway, consisting of basic education (Elementary School/Junior High School/equivalent), secondary education (Senior High School/

Table 1. The result of the reliability test of questionnaires on quality of service and patient satisfaction

\begin{tabular}{clcc}
\hline No & \multicolumn{1}{c}{ Variables } & Total-Item Correlation (r) & Cronbach's Alpha \\
\hline 1 & Tangible & $\geq 0.25$ & 0.87 \\
2 & Reliability & $\geq 0.35$ & 0.85 \\
3 & Responsiveness & $\geq 0.26$ & 0.84 \\
4 & Assurance & $\geq 0.34$ & 0.76 \\
5 & Empathy & $\geq 0.30$ & 0.73 \\
6 & Satisfaction & $\geq 0.29$ & 0.85 \\
\hline
\end{tabular}

vocational School/equivalent), and higher education (Academy/College/equivalent).

The level of insurance participation was defined as the participation of patients in health service financing guarantees.

Quality of service was defined as a measure of the progress of a service met the needs of customers or patients. The five dimensions of quality of service used were responsiveness, reliability, assurance, empathy, and tangible.

Satisfaction was defined as the pleasure of patients who came from the comparison between the services they received and their expectations.

\section{e. Reliability test}

Based on the result of the total-item correlation test, the measurement of accreditation status, education status, family income level, insurance participation status, quality of service, and patient satisfaction variables were $r$ count $\geq 0.25$ and Cronbach's alpha $\geq 0.75$, so that all questions were stated reliable.

\section{f. Data Analysis}

The data analysis of univariate quantitative were carried out to show the characteristic data and descriptive of variables of the study. Bivariate analysis aimed to analyze the effects of exogenous variables on endogenous variables using Chi-Square test. Multivariate analysis with path analysis was used to determine the direct and indirect effects between dependent and independent variables. 
Journal of Health Policy and Management (2017), 2(1): 91-100

https://doi.org/10.26911/thejhpm.2017.02.01.08

\section{RESULTS}

1. Univariate Analysis

Univariate analysis consisted of the characteristics of the study subjects and the study variables. The characteristics of the study subjects were explained in Table 2. The result of the univariate analysis on the study variables were explained in Table 3

Table 2. The characteristics of study subjects

\begin{tabular}{llcl}
\hline \multicolumn{1}{c}{ Characteristics } & \multicolumn{1}{c}{ Criteria } & Frequency & (\%) \\
\hline Age & $<40$ years & 91 & 45.5 \\
& 41-60 years & 61 & 30.5 \\
\multirow{3}{*}{ Gender } & $\geq 61$ years & 48 & 24.0 \\
\multirow{2}{*}{ Patient Education } & Male & 59 & 29.5 \\
& Female & 141 & 70.5 \\
Occupation & < SHS & 90 & 45.0 \\
& $\geq$ SHS & 110 & 55.0 \\
Income & Work at home & 66 & 33.0 \\
\multirow{2}{*}{ Number of Family Member } & Work outside & 134 & 67.0 \\
& $<$ minimum wage & 127 & 63.5 \\
& $\geq$ minimum wage & 73 & 36.5 \\
& $\geq 4$ members & 140 & 70.0 \\
\hline
\end{tabular}

Based on Table 2, there were 91 patients aged $<40$ years as study subjects at community health center (45.5\%). The majority of the study subjects were female by 141 patients (70.5\%). Most of the patients with $\geq$ Senior high school education were 110 people (55.0\%). Most of the patients who worked outside were 134 people (67.0\%). Most of the patients who had <minimum wage income were 127 people $(63.5 \%)$. The highest number of family members was $<4$ family members by 140 people (70.0\%).

Table 3. The descriptive analysis of the study variables

\begin{tabular}{lcccc}
\hline \multicolumn{1}{c}{ Variables } & Mean & SD & Minimum & Maximum \\
\hline Family income & 15.21 & 7.88 & 1 & 43 \\
Patient education & 0.55 & 0.50 & 0 & 1 \\
Patient occupation & 0.67 & 0.47 & 0 & 1 \\
Patient insurance status & 1.42 & 0.79 & 0 & 2 \\
Community health center & 1.50 & 1.21 & 0 & 3 \\
accreditation status & & & & 183 \\
Quality of service in community & 146.26 & 12.81 & 120 & 42 \\
health center & & & & 25 \\
Patient satisfaction & 32.43 & 3.55 & & \\
\hline
\end{tabular}

Table 3 shows that the descriptive analysis of descriptive study variables which was explained based on the minimum, maximum, mean, and standard deviation values had various data which was relatively small in each value.

\section{Bivariate Analysis}

Bivariate analysis was used to analyze the association between patient income, patient education, accreditation status of community health center, and quality of service in community health center and patient satisfaction.

Table 4 shows that family income $(\mathrm{r}=$ $-0.03, \mathrm{p}=0.688)$ and patient occupation $(\mathrm{r}=$ -001, $\mathrm{p}=0.846)$ had negative association which was statistically non-significant. Patient education $(r=-0.24, p=0.001)$ had 
positive association which was statistically significant. Patient insurance status ( $\mathrm{r}=$ 0.23, $\mathrm{p}=0.001$ ), accreditation status of community health center $(\mathrm{r}=0.17, \mathrm{p}=$ Table 4. The analysis of bivariate analysis on the determinants of patient satisfaction

\begin{tabular}{lcc}
\hline \multicolumn{1}{c}{ Independent Variables } & r & p \\
\hline Family income & -0.03 & 0.688 \\
Patient education & -0.24 & 0.001 \\
Patient occupation & -0.01 & 0.846 \\
Patient insturance status & 0.23 & 0.001 \\
Accreditation status of community health center & 0.17 & 0.019 \\
quality of service in community health center & 0.28 & $<0.001$ \\
\hline
\end{tabular}

\section{Path Analysis}

\section{a. Model Specification}

Model specification illustrated the association between variables studied. The observed variables in this study consisted of patient income, patient education, patient occupation, patient insurance status, accreditation status of community health center, and quality of service in community health center and patient satisfaction.

\section{b. Model Identification}

Variabel terukur terhadap kepuasan pasien: Observed variables on patient satisfaction:

1) Number of observed variables $=7$

2) Endogenous variables $=3$

3) Exogenous variables $=7$

4) Number of parameter $=34$

The formula of degree of freedom was:

$\mathrm{df}=$ (number of observed variables $\mathrm{x}$

(number of observed variables +1 ) ) $2-$

(endogenous variables + exogenous variables + number of parameter)

$=(7 \times(7+1)) / 2-(3+4+16)$

$=28-23$

$=5$

The result of degree of freedom (df) was 5 . Therefore, over identified or path analysis could be conducted.

Figure 1 shows the structural model after the estimation using SPSS Amos. Indi-
0.019), and quality of service in community health center $(\mathrm{r}=0.28, \mathrm{p}<0.001)$ had positive effects which were statistically significant. 
Journal of Health Policy and Management (2017), 2(1): 91-100

https://doi.org/10.26911/thejhpm.2017.02.01.08

Quality of service was affected by patient education, family income, occupation, patient insurance status, and accreditation status of community health center.

Each increase in one unit of education would decrease the score of quality of service level in community health center by 4.51. Each increase in one unit of family income would decrease the score of quality of service level in community health center by 0.17 .

Each increase in one unit of occupation would decrease the score of quality of service level in community health center by 3.93. Each increase in one unit of insurance status would increase the score of quality of service level in community health center by 2.79 .

Each increase in one unit of accreditation of community health center would increase the score of quality of service level in community health center by $\mathbf{2 . 2 2}$.

Insurance status was affected by family income. Each increase in one unit of family income would decrease the score of insurance status by 0.02 .

Each increase in one unit of duration of treatment would increase the score of inpatient quality of service by 0.37. Each increase in one unit of doctor's years of service would increase the score of inpatient quality of service by 0.13 . Each increase in one unit of insurance type would increase the score of inpatient quality of service by 1.04. Each increase in one unit of class type would increase the score of inpatient quality of service by 2.24 .

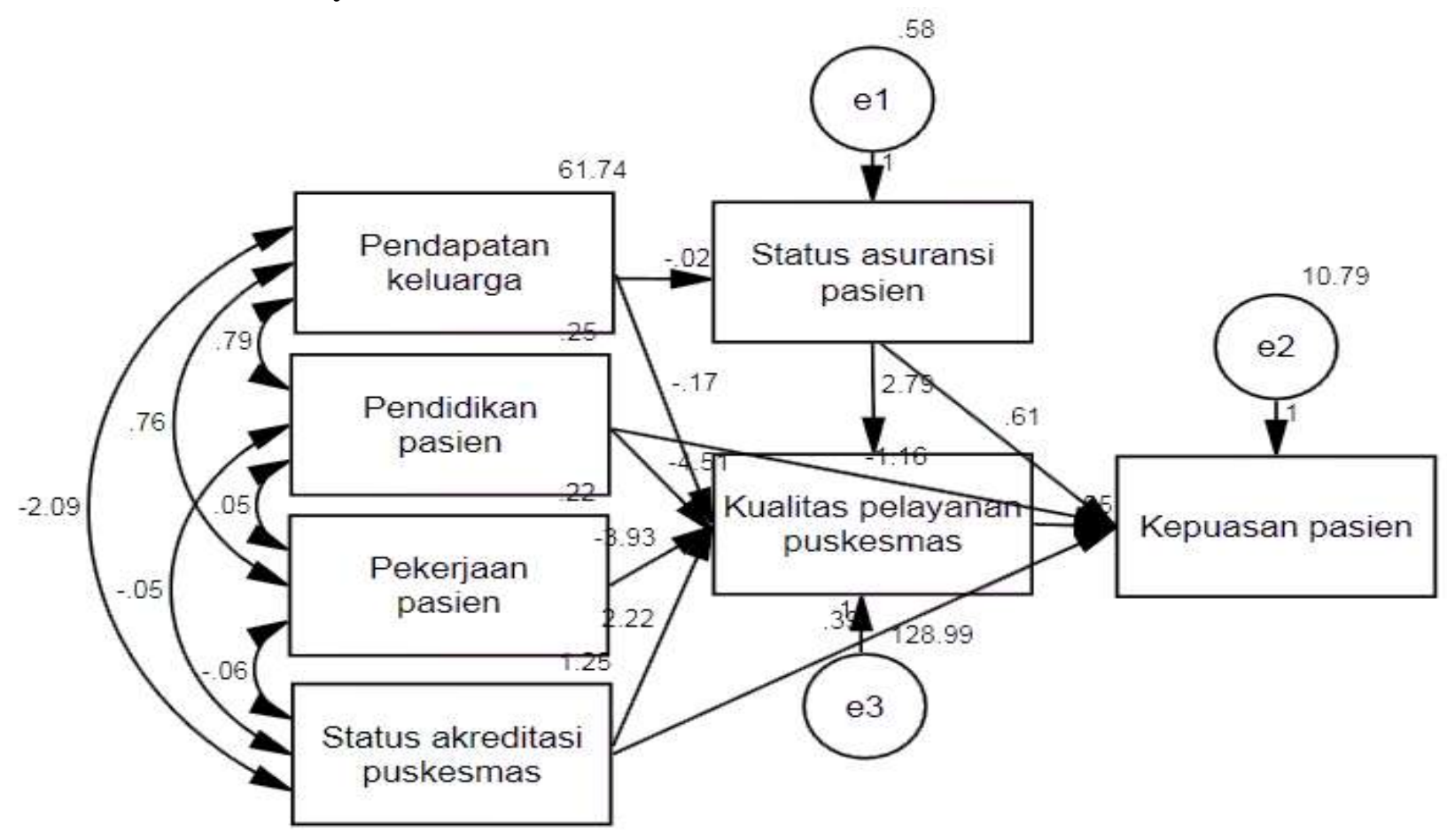

Figure 1. The structural model of path analysis with estimate 
Tabel 5. The result of path analysis of the effects of patient personal, doctor, payment method, and type of class on quality and satisfaction of service

\begin{tabular}{|c|c|c|c|c|c|c|}
\hline \multirow{2}{*}{\multicolumn{2}{|c|}{$\begin{array}{l}\text { Endogenous Variabl } \\
\text { Direct Effects }\end{array}$}} & Exogenosu Variables & $\mathbf{b}^{*}$ & SE & $\mathbf{P}$ & $\boldsymbol{\beta}^{* *}$ \\
\hline & & \multirow{2}{*}{ Education $\geq$ SHS } & \multirow[b]{2}{*}{-1.16} & \multirow[b]{2}{*}{0.48} & \multirow[b]{2}{*}{0.017} & \multirow[b]{2}{*}{-1.6} \\
\hline Satisfaction & $\mathrm{n} \longleftarrow$ & & & & & \\
\hline Satisfaction & & $\begin{array}{l}\text { Insurance of premium assistance } \\
\text { recipients }\end{array}$ & 0.61 & 0.30 & 0.044 & 0.14 \\
\hline Satisfaction & & Main accreditation & 0.39 & 0.22 & 0.069 & 0.13 \\
\hline Satisfaction & & Very good quality of service & 0.46 & 0.20 & 0.022 & 0.17 \\
\hline \multicolumn{2}{|c|}{ Indirect Effects } & \multirow[b]{2}{*}{ Education $\geq$ SHS } & & & & \\
\hline Quality & $\longleftarrow$ & & -4.51 & 1.68 & 0.007 & -0.18 \\
\hline Quality & & Income $\geq$ minimum wage & -0.17 & 0.11 & 0.123 & -0.11 \\
\hline Quality & & Work outside & -3.93 & 1.78 & 0.027 & -0.15 \\
\hline Quality & & $\begin{array}{l}\text { Insurance of premium assistance } \\
\text { recipients }\end{array}$ & 2.79 & 1.06 & 0.008 & 0.17 \\
\hline Quality & & \multirow{2}{*}{$\begin{array}{l}\text { Main accreditation } \\
\text { Income }\end{array}$} & 2.22 & 0.74 & 0.003 & \multirow{2}{*}{$\begin{array}{r}0.20 \\
-0.234\end{array}$} \\
\hline $\begin{array}{l}\text { Insurance } \\
\text { Model Fit }\end{array}$ & $\longleftarrow$ & & -0.02 & 0.01 & $<0.001$ & \\
\hline \multicolumn{7}{|c|}{$\begin{array}{l}\text { Model Fit } \\
p=0.061(>0.050)\end{array}$} \\
\hline CMIN & \multicolumn{2}{|l|}{$=10.534$} & & & & \\
\hline GFI & \multicolumn{2}{|c|}{$=0.92 \quad(>0.90)$} & CFI & \multicolumn{2}{|c|}{$=10.99(>0.90)$} & \\
\hline NFI & \multicolumn{2}{|c|}{$=0.95 \quad(>0.90)$} & RMSEA & \multirow{2}{*}{\multicolumn{2}{|c|}{$\begin{array}{l}=0.75(<0.80) \\
\text { path coefficient }\end{array}$}} & \\
\hline \multicolumn{3}{|c|}{${ }^{*}=$ unstandardized path coefficient } & \multicolumn{2}{|c|}{ ** standardized path coefficient } & & \\
\hline
\end{tabular}

\section{DISCUSSION \\ a. The effects accreditation status of community health center on qua- lity of service in the community health center}

Based on the result of path analysis in this study, there were effects of accreditation status of community health center on quality of service in the community health center and they were statistically significant.

This result of the study is in line with a study conducted by Goetz et al. (2015) that quality management which is in the accreditation process gives an increase in three of the four quality domains, namely quality and safety, information, and finance. The increase in the three quality domains affects the quality of service received and perceived by patients. In conclusion, the accreditation status of community health center affects quality of health service in the community health center. b. The effects of accreditation status of community health center on patient satisfaction in the community health center

Based on the result of path analysis in this study, there were effects of accreditation status of community health center on patient satisfaction in the community health center which were statistically close to significant.

This result of the study is in line with a study conducted by Goetz et al. (2015) that accreditation status affects quality of service of health facility. The result of the study states that quality management which is in the accreditation process affects the increase of quality of service especially in quality and safety domains, information, and finance.

According to Cong et al., (2014), the increase of quality of service empirically affects patient satisfaction. The increase of quality of service in three dimensions of service quality such as tangible, accessi- 
bility to health services, and medical behavior and ethics, affect patient satisfaction.

In conclusion, accreditation status of community health center affects patient satisfaction in the community health center.

\section{c. The effects of patient education level on basic quality of service in the community health center}

Based on the result of path analysis in this study, there were positive effects of patient education level on perceived quality of service in the community health center which were statistically significant. This study is in line by a study conducted by Otani et al. (2011) which examined the association between demographic factors such as age, gender, health status, and education level and patient satisfaction. A study conducted at 32 referral hospitals in the United States shows that patients age $>50$ years, patients with shorter duration of treatment or better health status, and with lower education level give higher score to domains related to health services. In conclusion, formal education level of patients affects perception of basic quality of service in the community health center.

\section{d. The effects of family income level on perceived quality of service}

Based on the result of path analysis in this study, family income did not affect on patient satisfaction and it was statistically significant.

The result of this study is supported by the result of a study conducted by Nguyen et al., (2003) and Jenkinson et al., (2002) that the main and consistent determinants that affect patient satisfaction are older age and better health status. Other patient characteristics such as age, gender, social status and so on have minimum effect on perceived quality of service and patient satisfaction.
In conclusion, the level of family income does not significantly affect perceived quality of service in the community health center.

\section{e. The effects of patient insurance status on perceived quality of ser- vice in the community health center}

Based on the result of path analysis in this study, there were positive effects of patient insurance status on perceived quality of service in the community health center which were statistically significant.

The result of this study is supported by a study conducted by Bohm (2013) that there was a significant variation in patient satisfaction depending on the types of insurance (MEDICARE, MEDICAID, employee insurance, and Canadian National Health Insurance). The highest patient satisfaction was found in the owners of MEDICARE insurance and the lowest was found in the owners of MEDICAID insurance. The highest patient satisfaction was obtained from patients who had national health insurance provided by the government. The cause of the difference in the level of satisfaction was the health care which patients need was not fullfiled. Patients who paid their premium tend to expect to get all treatments which were really needed or who only contribute little to the success of treatment.

Based on the result of this study, the patient satisfaction in the community health center is affected by patient education, patient insurance status, accreditation status of community health cener, and quality of service in community health center. Quality of service is affected by patient education, family income, occupation, patient insurance status, and accreditation status of community health center. In addition, insurance status is affected by family income. 


\section{REFERENCE}

Bohm, J (2013). Relating Patient Satisfaction to Insurance Coverage: A Comparison of Market Based and Government Sponsored Health Care. Academy of Business Research Journal.

Budiman, Suhat, Nyai Herlina (2010). Hubungan Status Demografi Dengan Kepuasan masyarakat Tentang Pelayanan Jamkesmasdi Wilayah Puskesmas Tanjungsari Kabupaten Bogor. Jurnal Kesehatan Kartika. Retrieved from http://stikesayani.ac.id/publikasi/e-journal/filesx/2010/201004/201004-006.pdf. Diakses 4 Januari 2017.

Cong NT, Mai NT (2014). Service Quality and Its Impact on Patient Satisfaction: An Investigation in Vietnamese Public Hospital. Journal of Emerging Economies and Islamic Research 2(1).

Dotchin JA, Oakland JS (1994). Total quality management in services: Part 2 Service quality. International Journal of Quality \& Reliability management: 11 (3): 27-42.

Edvardsen B, Tomasson B, Ovretveit J (1994). Quality of Service: Making it Really Work. McGraw-Hill: New York.

Goetz K, Hess S, Jossen M, Huber F, Rosemann T, Brodowski M, Kunzi B, et al. (2015). Does a Quality Management System Improve Quality in Primary Care Practices in Switzerland? A Longitudinal Study. BMJ Open, 5: eoo7443

Goetz K, Hess S, Jossen M, Huber F, Rosemann T, Brodowski M, Kunzi B, et al. (2015). Does a Quality Management System Improve Quality in Primary Care Practices in Switzerland? A Longitudinal Study. BMJ Open, 5: eoo7443
Hendra M (2004). Pengembangan Pola Berpikir. Retrieved from http://indonesia.siutao.com. tanggal 5 Mei 2017

Hudon C, Fortin M, Haggerty JL, Lambert M, Poitras ME (2011). Measuring patient's perception of patient centered care : a systematic review of tools for family medicine. Annals of Family Medicine. 9 (2) : 155- 164.

International Accreditation Forum (2015). Accreditation: Supporting the Delivery of Health and Social Care. Quebec: The IAF Secretariat.

Jenkinson C, Coulter A, Bruster S, Richards $\mathrm{N}$, Chandola T (2003). Patient's experience and satisfaction with health care: Results of a questionnaire study of specific aspects of care. Quality Safety Health Care, 11: 335-339.

Kemenkes RI (2014). Peraturan Menteri Kesehatan Republik Indonesia Nomor 75 tahun 2014 tentang Pusat Kesehatan Masyarakat. Jakarta: Kementerian Kesehatan Republik Indonesia.

Kemenkes RI (2015). Peraturan Menteri Kesehatan Republik Indonesia Nomor 46 tahun 2015 tentang Akreditasi Puskesmas, Klinik Pratama, Tempat Praktek Mandiri Dokter, dan Tempat Praktik Mandiri Dokter Gigi. Jakarta: Kementerian.

Lewis BR, Mitchell VW (1990). Defining and measuring the quality of customer service. Marketing Intellegence \& Planning: 8 (6):11-17.

Lovelock C, Wright LK (2005). Manajemen Pemasaran Jasa, Kelompok Gramedia, Indeks, Indonesia.

Mahendradhata Y, Utarini A, Kuntjoro T (2004). Development of Standards for Accreditation of Primary Care Services in Indonesia. Radcliff e Medical Press. Quality in Primary Care 2004; 12:73-7. 
Journal of Health Policy and Management (2017), 2(1): 91-100

https://doi.org/10.26911/thejhpm.2017.02.01.08

Morris C, Bailey K (2014). Measuring health care quality: An overview of quality measures. Washington DC: Familie USA

Naili (2016). Akreditasi Puskesmas, Pentingkah?. Retrieved from http://www.-

kompasiana.com/nailinsn/akreditasipuskemas-pentingkah_580acb16b37e61a2711a26e2 tanggal 5 Mei 2017.

Nguyen Thi PL, Briancon S, Empereur F, Guillemin F (2002). Factors Determining Inpatient Satisfaction with Care. Soc Sci Med, 54(4):493-504.

Nicklin W (2015). The Value and Impact of Health Care Accreditation: A Literature Review. Canada: Accreditation Canada.

Nouwens E, Lieshout JV, Wensing M (2015). Determinants of Impact of a Practice Accreditation Program in Primary Care: a Qualitative Study. BMC Family Practice 16:78.

O'Beirne M, Zwicker K, Sterling PD, Lait J, Robertson HL, Oelke ND (2013). The status of accreditaion in primary care. Quality in Primary Care2013; 21:2331.

Otani K, Herrmann PA, Kurz RS (2014). Improving patient satisfaction in Hospital Care Settings. Health Serv Manage Res, 24940: 163-169.

Parasuraman A, Zeithaml VA, Berry LL (1985). A conceptual model of service quality and its implication. Journal of Marketing: 49: 41-50.

Pohan, (2003). Jaminan Mutu Pelayanan Kesehatan. Kesaint Blane: Bekasi.

Radja (2015). Asuransi Kesehatan Sosial Dan Biaya Out Of Pocket Di Indonesia Timur. Retrieved from http://etd.repository.ugm.ac.id/index.php.

Diakses 15 Desember 2016.
Rowland F, Syed-Ikhsan SOS (2004). Knowledge management in a public organization: a study on the relationship between organizational elements and the performance of knowledge transfer", Journal of Knowledge Management, 8(2): 95-111.

Sareen J, Jagdeo A, Cox BJ, Clara I, ten Have M, Belik SL, Stein MB (2007). Perceived barriers to mental health service utilization in the United States, Ontario, and the Netherlands. Psychiatric Services: 58: 357-364.

Shahin (2006). SERVQUAL and Model of Service Quality Gaps: A framework for determining and prioritizing critical factors in delivering quality service. Retrieved from https://www.researchgate.net/publication/237703019. Diakses Desember 2016.

Sumarsono S (2009). Ekonomi Sumber Daya Manusia Teori dan Kebijakan Publik. Graha Ilmu: Jogyakarta

Utami IW, Yuliana ME, Hastuti I (2016). Perbandingan Kualitas Pelayanan Puskesmas Pajang Sebelum dan Sesudah Tersertifikasi ISO 9001: 2008. Prosiding Nasional APIKES-AKBID Citra Medika Surakarta: 226-230.

Wang P, Lane M, Olfson M, Pincus HA, Wells KB, Kessler RC (2005). Twelvemonth use of mental health services in the United States: Results from the national comorbidity survey replication. Archives of General Psychiatry: 62: 629-640.

Wicaksono TW (2004). Besarkah Manfaat Pendidikan Tinggi terhadap Pembangunan Ekonomi?, Harian Kompas 21 Agustus 2004. Diambil dari www.kompas-online.com 16 Mei 2017. 